\title{
Inter- and independent effects of region and race/ethnicity on variety of fruit and vegetable consumption in the USA: 2011 Behavioral Risk Factor Surveillance System (BRFSS)
}

\author{
Nicole Tichenor* and Zach Conrad \\ Friedman School of Nutrition Science and Policy, Tufts University, 150 Harrison Avenue, Boston, MA 02111 , USA
}

Submitted 11 April 2014: Final revision received 15 November 2014: Accepted 15 January 2015: First published online 6 March 2015

\begin{abstract}
Objective: (i) To estimate the independent and combined effects of race/ethnicity and region on the variety of fruits and vegetables consumed in the USA in 2011; and (ii) to assess whether and to what extent race/ethnicity and region may synergistically influence variety of fruit and vegetable consumption.

Design: Cross-sectional analysis. Multivariate logistic regression predicted the likelihood of meeting fruit and vegetable variety indicators independently and in combination for each race/ethnicity and region. Interaction effects models were used to test for interaction effects between race/ethnicity and region on fruit and vegetable variety.

Setting: The 2011 Behavioral Risk Factor Surveillance System (BRFSS).

Subjects: The sample consisted of 275864 adult respondents.

Results: Fewer than half of respondents consumed fruit and all vegetable subcategories at least once weekly. The adjusted likelihood of meeting fruit and vegetable variety indicators varied significantly by race/ethnicity and region $(P<0.05)$. Significant interactions between race/ethnicity and region were found for at least once weekly consumption of beans, orange vegetables, all vegetables, and fruit and all vegetables $(P<0.05)$.

Conclusions: Our results reinforce previous findings that the variety of vegetable consumption is lacking and is particularly evident among some population subgroups, such as non-Hispanic blacks in the Midwest USA, who may benefit from targeted dietary interventions.
\end{abstract}

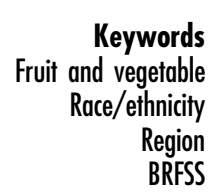

Consuming a diet rich in fruits and vegetables is associated with a decreased risk of $\mathrm{CVD}^{(1-4)}$, the leading cause of mortality in the USA ${ }^{(5)}$. When incorporated into an overall healthy lifestyle, regular consumption of fruits and vegetables is associated with a reduced risk of all-cause mortality ${ }^{(6)}$. A growing body of evidence also shows a positive relationship between dietary variety and micronutrient intake ${ }^{(7-9)}$. Accordingly, the 2010 Dietary Guidelines for Americans provide recommendations for consuming adequate amounts and variety of fruits and vegetables. Yet, despite an ongoing national programme to improve consumption habits ${ }^{(10)}$, the proportion of Americans meeting these guidelines remains low ${ }^{(11-14)}$. Marked differences in consumption patterns have been observed across race/ ethnic groups $^{(15,16)}$ as well as regions of residence ${ }^{(12)}$ and, importantly, some evidence suggests that race/ethnicity and region of residence may synergistically influence consumption patterns ${ }^{(17-19)}$. These findings suggest that determinants of fruit and vegetable consumption may be more nuanced than had previously been understood and that highly targeted dietary interventions may be needed for certain population groups. Examining the relationship of race/ethnicity and region of residence with fruit and vegetable consumption is therefore critical to improving Americans' food consumption habits.

Differences in fruit and vegetable consumption across racial/ethnic groups have been well demonstrated $^{(11,12,14-16,19-25)}$. Studies have found that nonHispanic blacks consume fewer fruits and vegetables than other race/ethnic groups ${ }^{(14-16,20,22,24-27)}$, although more recent findings suggest otherwise ${ }^{(11,21)}$. Several studies have described differences in fruit and vegetable consumption across regions ${ }^{(16,28,29)}$, with results indicating more favourable consumption patterns in the West and Northeast compared with the South and Midwest. According to the US Census Bureau ${ }^{(30)}$, the West region 
includes the Pacific Coast and stretches east to Colorado, where it meets the Midwest and the South. The South stretches from Texas and Oklahoma up to New Jersey, where the Northeast begins. Few studies have explored the interaction between region and race/ethnicity on food consumption and nutrient intake, but those that have suggest region may have a modifying effect on race/ ethnicity ${ }^{(17-19)}$. Our objectives in the present work were to: (i) estimate the independent and combined effects of race/ethnicity and region on the variety of fruits and vegetables consumed; and (ii) assess whether and to what extent race/ethnicity and region may synergistically influence variety of fruit and vegetable consumption.

\section{Materials and methods}

We used the 2011 Behavioral Risk Factor Surveillance System (BRFSS) for the current analysis. The BRFSS is a telephone survey administered by US state health departments in partnership with the Centers for Disease Control and Prevention. Data are collected on health risk behaviours and preventive health practices of the US civilian population aged $\geq 18$ years. Over 500000 individuals are interviewed each year, making it the largest telephone-based survey in the world. Random digit dialing is used to select an independent probability sample of residents in each state and trained interviewers administer identical core questionnaires to one adult per household.

Two key changes were made to the 2011 BRFSS sampling design that make this data set particularly attractive for our analysis. A cell phone sampling frame was added to account for the nearly one-third of US households that use a cell phone instead of a landline telephone ${ }^{(31)}$. As racial/ethnic minorities, renters and low-income populations are more likely to live in households with a cell phone instead of a landline telephone, this sampling frame better represents the population of interest in our study compared with BRFSS sampling frames from previous years $^{(32)}$. Additionally, the weighting methodology was changed from a post-stratification approach to a raking approach (also known as iterative proportional fitting), where the sample data is weighted to fit the distribution of control variables, making the sample more reflective of sociodemographic characteristics within each state ${ }^{(31)}$.

Fruit and vegetable consumption frequencies were measured by six questions in the BRFSS core module: (i) 'During the past month, how many times per day, week or month did you drink $100 \%$ PURE fruit juices? Do not include fruit-flavoured drinks with added sugar or fruit juice you made at home and added sugar to. Only include $100 \%$ fruit juice.' (ii) 'During the past month, not counting juice, how many times per day, week or month did you eat fruit? Count fresh, frozen or canned fruit.' (iii) 'During the past month, how many times per day, week or month did you eat cooked or canned beans, such as refried, baked, black, garbanzo beans, beans in soup, soyabeans, edamame, tofu or lentils? Do NOT include long green beans.' (iv) 'During the past month, how many times per day, week or month did you eat dark green vegetables; for example, broccoli or dark leafy greens including romaine, chard, collard greens or spinach?' (v) 'During the past month, how many times per day, week or month did you eat orange-coloured vegetables such as sweet potatoes, pumpkin, winter squash or carrots?' (vi) 'Not counting what you just told me about, during the past month, about how many times per day, week or month did you eat OTHER vegetables? Examples of other vegetables include tomatoes, tomato juice or V-8 juice, corn, eggplant, peas, lettuce, cabbage and white potatoes that are not fried, such as baked or mashed potatoes?'

An overall fruit and vegetable variety indicator was operationalized as consuming fruit as well as each subgroup of vegetables (beans, dark green vegetables, orange vegetables and other vegetables) $\geq 1$ time/week, informed by the Food Patterns recommendations for vegetable subgroup consumption on a weekly basis in the Dietary Guidelines for Americans 2010 from the US Department of Agriculture $^{(33)}$. Individual vegetable subgroups and fruit consumed $\geq 1$ time/week were also analysed to explore differences in variety of consumption. As the Food Patterns subcategory recommendations are servings-based and tailored to energy intake, adherence to variety recommendations could not be modelled due BRFSS data limitations.

Main predictor variables were race/ethnicity (nonHispanic white, non-Hispanic black, non-Hispanic other races, Hispanic) and region (South, Midwest, Northeast, West). A total of 504408 people completed the interviews. Covariates were identified and operationalized according to precedent set by others and included gender, age, education, income, smoking status, BMI and physical activity ${ }^{(16,28)}$. Physical activity level included occupational and leisure-time physical activity, and was categorized as sufficient (150 min of moderate-intensity or $75 \mathrm{~min}$ of vigorous intensity aerobic exercise per week) ${ }^{(34)}$, insufficient (active but not sufficient) and inactive (no occupational or leisure-time physical activity). Respondents omitting information on fruit and vegetable consumption or covariates, in addition to those who reported consuming fruit $>16$ times/d or vegetables $>23$ times/d, were excluded $^{(12,16,22)}$ ( $n$ 228 544). Persons who responded to all fruit and vegetable questions but reported zero consumption were assigned a frequency of $0 \cdot 1$ times/month to allow for inclusion in the analysis ${ }^{(16)}$. A total of 275864 respondents were included in the final sample. Respondents were grouped into four regions (South, Northeast, Midwest, and West) according to the US Census Bureau categorization scheme ${ }^{(30)}$.

Multivariate logistic regression was performed on weighted data to estimate odds ratios after adjusting for covariates. Main effects models predicted the likelihood of 
consuming fruits and vegetable subcategories at least once weekly independently and in combination for each race/ ethnicity and region. Interaction effects models were used to test for the presence and magnitude of interaction effects between race/ethnicity and region on fruit and vegetable variety. The statistical significance of interaction terms was computed in a two-step process. Logistic regression models were used to estimate the odds ratios for interaction terms and a subsequent Wald test was executed to determine whether the odds ratios for the interaction terms within each fruit and vegetable category were significantly different from one another in aggregate. Interaction terms were statistically significant if deemed so by the logistic regression model and the Wald test. Statistical significance was set at $P<0.05$ and all hypothesis tests were two-tailed. The statistical software package Stata 12 was used to account for the complex sampling design and to calculate weighted effect sizes.

\section{Results}

\section{Respondent characteristics}

Approximately half of all respondents in each region were female. The age distribution of respondents in each region was similar, with the greatest proportion of respondents aged $45-54$ years and the lowest proportion aged $\geq 75$ years (Table 1). Non-Hispanic white respondents represented the majority racial/ethnic group in all regions, but the greatest proportions were found in the Midwest and Northeast. Compared with other regions, a greater proportion of nonHispanic black respondents were found in the South, and a greater proportion of Hispanic respondents and those reporting other race/ethnicities were located in the West. More than half of respondents in each region reported completing some college, with the highest proportion located in the Northeast. More than half of respondents in each region were non-smokers, with the highest proportion

Table 1 Demographic characteristics of respondents by region, Behavioral Risk Factor Surveillance System (BRFSS) 2011

\begin{tabular}{|c|c|c|c|c|c|}
\hline Characteristic & South $\left(n 76\right.$ 160) $\left(\%^{*}\right) \dagger$ & Midwest (n 67 991) (\%*) & Northeast ( $n 53$ 386) (\%*) & West (n 78 327) $\left(\%{ }^{\star}\right)$ & $P$ value \\
\hline Sex (\% female) & $48 \cdot 5$ & $48 \cdot 8$ & $47 \cdot 9$ & $48 \cdot 3$ & 0.054 \\
\hline Age group (years) & & & & & $<0.001$ \\
\hline $18-24$ & $12 \cdot 2$ & $12 \cdot 4$ & 11.5 & $12 \cdot 8$ & \\
\hline $25-34$ & 19.5 & $18 \cdot 7$ & $17 \cdot 4$ & $19 \cdot 2$ & \\
\hline $35-44$ & $19 \cdot 3$ & 18.5 & 18.4 & $19 \cdot 0$ & \\
\hline $45-54$ & $20 \cdot 0$ & $20 \cdot 2$ & $21 \cdot 3$ & $19 \cdot 5$ & \\
\hline $55-64$ & $15 \cdot 0$ & $15 \cdot 5$ & $16 \cdot 0$ & $15 \cdot 0$ & \\
\hline $65-74$ & 8.7 & 8.7 & 8.9 & 8.6 & \\
\hline$\geq 75$ & $5 \cdot 8$ & $6 \cdot 0$ & $6 \cdot 4$ & 5.9 & \\
\hline Race/ethnicity & & & & & $<0.001$ \\
\hline Non-Hispanic white & $66 \cdot 5$ & $82 \cdot 2$ & $75 \cdot 2$ & $60 \cdot 0$ & \\
\hline Non-Hispanic black & $16 \cdot 3$ & 8.7 & $9 \cdot 0$ & 4.0 & \\
\hline Non-Hispanic, other & $4 \cdot 7$ & $4 \cdot 1$ & $6 \cdot 6$ & $13 \cdot 6$ & \\
\hline Hispanic & 12.5 & $5 \cdot 1$ & $9 \cdot 2$ & 22.6 & \\
\hline Education & & & & & $<0.001$ \\
\hline Less than high school & 11.5 & $8 \cdot 6$ & $9 \cdot 0$ & $12 \cdot 1$ & \\
\hline High school or equivalent & 26.9 & $28 \cdot 2$ & 26.9 & $22 \cdot 8$ & \\
\hline Some college & 31.5 & 33.3 & 27.5 & $34 \cdot 1$ & \\
\hline College graduate & $30 \cdot 1$ & $29 \cdot 9$ & 36.6 & $31 \cdot 0$ & \\
\hline Smoking status & & & & & $<0.001$ \\
\hline Non-smoker & $56 \cdot 2$ & $54 \cdot 0$ & $55 \cdot 2$ & $60 \cdot 8$ & \\
\hline Former smoker & $24 \cdot 0$ & $25 \cdot 4$ & 27.5 & $24 \cdot 7$ & \\
\hline Current smoker & $19 \cdot 8$ & $20 \cdot 6$ & $17 \cdot 3$ & 14.5 & \\
\hline Physical activity level & & & & & $<0.001$ \\
\hline Inactive & $2 \cdot 7$ & 1.7 & $2 \cdot 3$ & 1.5 & \\
\hline Insufficient & 30.5 & $30 \cdot 0$ & $27 \cdot 6$ & $27 \cdot 1$ & \\
\hline Sufficient & $66 \cdot 8$ & $68 \cdot 3$ & $70 \cdot 1$ & 71.4 & \\
\hline BMI $\left(\mathrm{kg} / \mathrm{m}^{2}\right)$ & & & & & $<0.001$ \\
\hline$<25$ & 35.9 & $35 \cdot 6$ & $39 \cdot 7$ & $40 \cdot 6$ & \\
\hline $25-<30$ & $36 \cdot 8$ & $37 \cdot 6$ & $37 \cdot 3$ & $36 \cdot 8$ & \\
\hline$\geq 30$ & $27 \cdot 4$ & $26 \cdot 8$ & 23.0 & 22.6 & \\
\hline Annual income (\$US) & & & & & $<0.001$ \\
\hline$<10000$ & $6 \cdot 0$ & $4 \cdot 6$ & $4 \cdot 8$ & $6 \cdot 6$ & \\
\hline $10000-<15000$ & $5 \cdot 7$ & 4.4 & 4.2 & 5.9 & \\
\hline $15000-<20000$ & 8.4 & $6 \cdot 9$ & 6.9 & 6.6 & \\
\hline $20000-<25000$ & $9 \cdot 5$ & $9 \cdot 0$ & $7 \cdot 6$ & $8 \cdot 1$ & \\
\hline $25000-<35000$ & $10 \cdot 7$ & $11 \cdot 7$ & 9.3 & $10 \cdot 6$ & \\
\hline $35000-<50000$ & $14 \cdot 3$ & 14.9 & $13 \cdot 1$ & $13 \cdot 3$ & \\
\hline $50000-<75000$ & $15 \cdot 2$ & $18 \cdot 1$ & $15 \cdot 9$ & $15 \cdot 5$ & \\
\hline$\geq 75000$ & $30 \cdot 2$ & $30 \cdot 4$ & $38 \cdot 2$ & $33 \cdot 3$ & \\
\hline
\end{tabular}

${ }^{*}$ Percentages are weighted.

†Sample sizes are unweighted.

fInter-regional differences were examined using the two-tailed design-adjusted Pearson $\chi^{2}$ statistic. 
located in the West. At least two-thirds of respondents in each region reported sufficient physical activity levels. The proportion of respondents reporting $\mathrm{BMI} \geq 30 \cdot 0 \mathrm{~kg} / \mathrm{m}^{2}$ ranged from nearly $23 \%$ in the West to over $27 \%$ in the South. Within each region, the greatest proportion of respondents reported earning $\geq \$$ US 75000 per annum.

\section{Prevalence and likelibood of consuming fruit and vegetables at least once weekly}

Approximately $42 \%$ of respondents reported consuming fruit and all vegetables $\geq 1$ time/week, with the lowest proportion reported among non-Hispanic blacks (28.6\%) and respondents in the Midwest (37.3\%); similar consumption patterns were observed for consuming all vegetables $\geq 1$ time/week (Table 2 ). There were no large disparities between races or regions for consuming fruit, other vegetables or dark green vegetables $\geq 1$ time/week. Nearly two-thirds of respondents reported consuming orange vegetables $\geq 1$ time/week, which was similar across all regions and race/ethnicities, except for nonHispanic blacks. Nearly two-thirds of respondents reported consuming beans $\geq 1$ time/week, which was highest among Hispanics and in the West, and lowest among nonHispanic blacks and in the Northeast.

Compared with non-Hispanic white respondents, nonHispanic black respondents were least likely to consume each category of fruit and vegetables $\geq 1$ time/week except for dark green vegetables, and Hispanics were most likely to consume each category of fruit and vegetables $\geq 1$ time/ week except for other vegetables (Table 3 ). Compared with

Table 2 Percentage of respondents consuming fruit and vegetables at least once weekly by race/ethnicity and region, Behavioral Risk Factor Surveillance System (BRFSS) 2011

\begin{tabular}{|c|c|c|c|c|c|c|c|c|c|c|c|c|c|c|}
\hline \multirow[b]{3}{*}{ Characteristic } & & & \multicolumn{8}{|c|}{ Vegetables } & & & & \\
\hline & \multicolumn{2}{|c|}{ Fruit $^{*}$} & \multicolumn{2}{|c|}{ Beans } & \multicolumn{2}{|c|}{ Dark green } & \multicolumn{2}{|c|}{ Orange } & \multicolumn{2}{|c|}{ Other } & \multicolumn{2}{|c|}{ All vegetables } & \multicolumn{2}{|c|}{ Fruit and all vegetables } \\
\hline & $\%$ & SE & $\%$ & SE & $\%$ & SE & $\%$ & SE & $\%$ & SE & $\%$ & SE & $\%$ & SE \\
\hline Overall & $95 \cdot 4$ & 0.08 & 63.8 & 0.19 & 85.5 & 0.14 & 63.9 & 0.19 & $94 \cdot 1$ & 0.11 & $42 \cdot 4$ & 0.19 & 41.9 & 0.19 \\
\hline \multicolumn{15}{|l|}{ Race/ethnicity } \\
\hline Non-Hispanic white & 95.5 & 0.08 & 63.1 & 0.20 & 86.0 & 0.15 & 65.4 & 0.20 & $96 \cdot 2$ & 0.09 & $43 \cdot 1$ & 0.21 & $42 \cdot 6$ & 0.21 \\
\hline Non-Hispanic black & 93.5 & 0.34 & $51 \cdot 8$ & 0.71 & $81 \cdot 8$ & 0.57 & 51.3 & 0.57 & $86 \cdot 4$ & 0.50 & 29.3 & 0.63 & 28.6 & 0.63 \\
\hline Non-Hispanic, other & $96 \cdot 2$ & 0.31 & $64 \cdot 2$ & 0.85 & 88.4 & 0.53 & 68.0 & 0.81 & 93.9 & 0.40 & 45.9 & 0.87 & $45 \cdot 5$ & 0.87 \\
\hline Hispanic & $96 \cdot 2$ & 0.27 & $77 \cdot 1$ & 0.62 & $84 \cdot 1$ & 0.57 & 63.6 & 0.71 & 89.5 & 0.47 & $47 \cdot 1$ & 0.72 & $46 \cdot 5$ & 0.72 \\
\hline \multicolumn{15}{|l|}{ Region } \\
\hline South & 94.3 & $0 \cdot 16$ & $66 \cdot 2$ & 0.33 & 84.0 & 0.27 & $61 \cdot 2$ & 0.35 & 93.5 & 0.19 & 41.6 & 0.34 & $40 \cdot 9$ & 0.34 \\
\hline Midwest & 95.4 & 0.17 & 58.3 & 0.40 & 82.6 & 0.31 & $61 . \overline{6}$ & 0.40 & $95 \cdot 1$ & 0.20 & 37.8 & 0.38 & $37 \cdot 3$ & 0.38 \\
\hline Northeast & $95 \cdot 7$ & 0.18 & $56 \cdot 2$ & 0.45 & 87.9 & 0.31 & $66 \cdot 6$ & 0.44 & 94.3 & 0.22 & 40.1 & 0.45 & 39.7 & 0.45 \\
\hline West & $96 \cdot 7$ & 0.13 & $70 \cdot 5$ & 0.36 & 88.5 & 0.25 & $67 \cdot 8$ & 0.37 & 94.0 & 0.22 & 49.0 & 0.39 & $48 \cdot 6$ & 0.39 \\
\hline
\end{tabular}

All values are statistically significant at the 0.01 level; differences were examined using the two-tailed design-adjusted Pearson $X^{2}$ statistic. Design-adjusted df $=496586$.

*Whole fruit and/or $100 \%$ fruit juice.

Table 3 Adjusted odds ratios of respondents consuming fruit and vegetables at least once weekly, Behavioral Risk Factor Surveillance System (BRFSS) 2011

\begin{tabular}{|c|c|c|c|c|c|c|c|c|c|c|c|c|c|c|}
\hline \multirow[b]{3}{*}{ Characteristic } & \multirow{2}{*}{\multicolumn{2}{|c|}{ Fruit $^{*}$}} & \multicolumn{8}{|c|}{ Vegetables } & \multirow{2}{*}{\multicolumn{2}{|c|}{ All vegetables }} & \multirow{2}{*}{\multicolumn{2}{|c|}{$\begin{array}{l}\text { Fruit and all } \\
\text { vegetables }\end{array}$}} \\
\hline & & & & Beans & $\mathrm{Da}$ & irk green & & Orange & & Other & & & & \\
\hline & OR & $95 \% \mathrm{Cl}$ & OR & $95 \% \mathrm{Cl}$ & OR & $95 \% \mathrm{Cl}$ & OR & $95 \% \mathrm{Cl}$ & OR & $95 \% \mathrm{Cl}$ & OR & $95 \% \mathrm{Cl}$ & OR & $95 \% \mathrm{Cl}$ \\
\hline \multicolumn{15}{|l|}{ Race/ethnicity } \\
\hline $\begin{array}{l}\text { Non-Hispanic } \\
\text { white }\end{array}$ & & Referent & & Referent & & Teferent & & Referent & & Referent & & Referent & \multicolumn{2}{|c|}{ Referent } \\
\hline $\begin{array}{l}\text { Non-Hispanic } \\
\text { black }\end{array}$ & 0.98 & $0.87,1 \cdot 12$ & 0.66 & $0.62,0.70$ & 1.02 & $0.93,1.11$ & 0.68 & $0.64,0.72$ & 0.35 & $0.31,0.39$ & 0.65 & $0.61,0.70$ & 0.64 & $0.60,0.68$ \\
\hline $\begin{array}{l}\text { Non-Hispanic, } \\
\text { other }\end{array}$ & $1 \cdot 10$ & $0.92,1.30$ & 0.95 & $0.88,1.02$ & $1 \cdot 15$ & $1 \cdot 03,1 \cdot 28$ & $1 \cdot 10$ & $1.02,1 \cdot 19$ & 0.67 & $0.58,0.78$ & 1.04 & $0.96,1.11$ & 1.04 & $0.96,1.12$ \\
\hline Hispanic & 1.69 & $1.43,2.00$ & 1.96 & $1 \cdot 81,2 \cdot 11$ & 1.23 & $1 \cdot 12,1.36$ & 1.17 & $1.09,1.25$ & 0.59 & $0.53,0.67$ & 1.39 & $1.30,1.48$ & 1.38 & $1.30,1.48$ \\
\hline $\begin{array}{l}\text { Region } \\
\text { South }\end{array}$ & \multicolumn{2}{|c|}{ Referent } & \multicolumn{2}{|c|}{ Referent } & \multicolumn{2}{|c|}{ Referent } & \multicolumn{2}{|r|}{ Referent } & \multicolumn{6}{|c|}{ Region } \\
\hline Midwest & 1.24 & $1 \cdot 12,1.36$ & 0.71 & $0.68,0.75$ & 0.87 & $0.82,0.93$ & 0.99 & $0.94,1.03$ & 1.09 & $0.98,1.21$ & 0.83 & $0.79,0.87$ & 0.84 & $0.80,0.87$ \\
\hline Northeast & 1.22 & $1 \cdot 10,1 \cdot 35$ & 0.62 & $0.59,0.65$ & 1.26 & $1.17,1.35$ & $1 \cdot 16$ & $1 \cdot 11,1 \cdot 22$ & 0.93 & $0.84,1.04$ & 0.86 & $0.82,0.90$ & 0.87 & $0.83,0.91$ \\
\hline West & 1.47 & $1.33,1.63$ & 1.06 & $1 \cdot 01,1 \cdot 11$ & 1.36 & $1 \cdot 27,1.45$ & 1.19 & $1 \cdot 14,1 \cdot 25$ & 0.96 & $0.87,1.07$ & $1 \cdot 19$ & $1 \cdot 14,1 \cdot 25$ & $1 \cdot 20$ & $1 \cdot 15,1.25$ \\
\hline
\end{tabular}

Design-adjusted $\mathrm{df}=496586$.

Adjusted for gender, age, education, smoking status, physical activity, BMI and income.

*Whole fruit and/or $100 \%$ fruit juice. 
respondents in the South, respondents in the Midwest were less likely to consume each category of fruits and vegetables $\geq 1$ time/week except for fruit and other vegetables, and respondents in the West were more likely to consume each category of fruits and vegetables $\geq 1$ time/week except for other vegetables.

Populations with relatively low likelihoods of meeting fruit and vegetable variety indicators can be identified by multiplying race/ethnicity coefficients with region coefficients. This reveals relatively low likelihoods of consuming fruit and all vegetables $\geq 1$ time/week for non-Hispanic blacks in the Midwest (OR: $0.64 \times 0.84=0.54$ ) and nonHispanic blacks in the Northeast (OR: $0.64 \times 0.87=0.56$; Table 3), who were almost $50 \%$ less likely to meet this indicator than non-Hispanic whites in their regions. NonHispanic blacks in these regions also had the lowest likelihoods for consuming all vegetables $\geq 1$ time/week and beans $\geq 1$ time/week.

\section{Interaction effect of race/etbnicity and region on consuming fruit and vegetables at least once weekly}

Table 4 displays the odds ratios for race/ethnicity $\times$ region interaction terms for each race/ethnicity and region combination. Statistically significant interactions were observed for fruit and all vegetables, all vegetables, beans and orange vegetables. All statistically significant interaction effects were observed in the Northeast and Midwest, with most observed in the Northeast. For consuming beans $\geq 1$ time/week, orange vegetables $\geq 1$ time/week, all vegetables $\geq 1$ time/week, and fruit and all vegetables $\geq 1$ time/ week, the relationship between non-Hispanic blacks and non-Hispanic whites in the Northeast was significantly different from the relationship between these race/ethnicities in all other regions.

\section{Examination of intraregional disparities by incorporating interaction effects}

The likelihood of meeting variety indicators by region and races within regions, accounting for interaction effects, is displayed in Table 5. Non-Hispanic blacks were 40\% less likely than non-Hispanic whites to consume fruit and all vegetables $\geq 1$ time/week in the South, Midwest and West (Table 5). There was no difference between nonHispanic blacks and whites in the Northeast on this indicator, due to a synergistic effect between race/ethnicity and region highlighted in Table 4. A similar pattern was observed for non-Hispanic blacks consuming all vegetables $\geq 1$ time/week.

Non-Hispanic blacks in the South, Midwest and West were $\sim 40 \%$ less likely to consume beans than nonHispanic whites in these regions (Table 5). However, in the Northeast, non-Hispanic blacks were $16 \%$ more likely to consume beans $\geq 1$ time/week than non-Hispanic whites, due to the positive interaction effect displayed in Table 4. In all regions, Hispanics were more likely to consume beans $\geq 1$ time/week than non-Hispanic whites
(Table 5), but the positive interaction effect in the Northeast (Table 4) enhanced this gap.

There was no difference in the likelihood of consuming orange vegetables $\geq 1$ time/week between Hispanics and non-Hispanic whites in the Northeast (Table 5); this was the only example found of a negative interaction (i.e. OR $<1.00$ ) between race/ethnicity and region (Table 4). In the South and West, Hispanics were 21 and $26 \%$ more likely, respectively, to consume orange vegetables compared with non-Hispanic whites in these regions (Table 5).

\section{Discussion}

The present study provides findings of the prevalence and likelihood of meeting fruit and vegetable variety indicators and elucidates the possible interaction effects between race/ethnicity and region of residence. Using the BRFSS 2011 data, which included a new survey methodology to enhance the representativeness of minority populations, and revised FFQ categories, these data may better reflect potential disparities in fruit and vegetable consumption than prior BRFSS iterations.

The results generated by the study show that a greater proportion of respondents consumed fruit $\geq 1$ time/week and other vegetables $\geq 1$ time/week compared with each of the other fruit and vegetable categories (Table 2). This may be concerning for two reasons. First, nearly $30 \%$ of respondents reported consuming their fruit as juice $\geq 50 \%$ of the time (data not shown) and nearly $10 \%$ of respondents reported consuming their fruit as juice $\geq 70 \%$ of the time. Diets that include more fruit juice than whole fruit have been associated with an increased risk of type 2 diabetes $^{(35)}$, which suggests that the form in which fruit is consumed may be just as important as the amount of fruit that is consumed. Second, our results reinforce previous findings that the variety of vegetable consumption is lacking ${ }^{(9,36)}$. Among all race/ethnic groups, consumption of vegetables is skewed towards other vegetables (which includes starchy vegetables, such as non-fried potatoes), a finding that has also been observed by others ${ }^{(13,37)}$. Further research should assess which regions and race/ ethnicities may require targeted interventions to substitute whole fruit for fruit juice and to increase the variety of vegetable consumption.

Testing the interaction between race/ethnicity and region allows for the identification of synergistic influences between race/ethnicity and region on fruit and vegetable consumption. Hispanics in the Northeast were impacted by an interaction, but in a mixed way. Being Hispanic in the Northeast was associated with a significant synergistic effect on consuming beans $\geq 1$ time/week and a negative effect on consuming orange vegetables $\geq 1$ time/week.

We identify non-Hispanic blacks in the Northeast as the population group that was most affected by the synergistic 


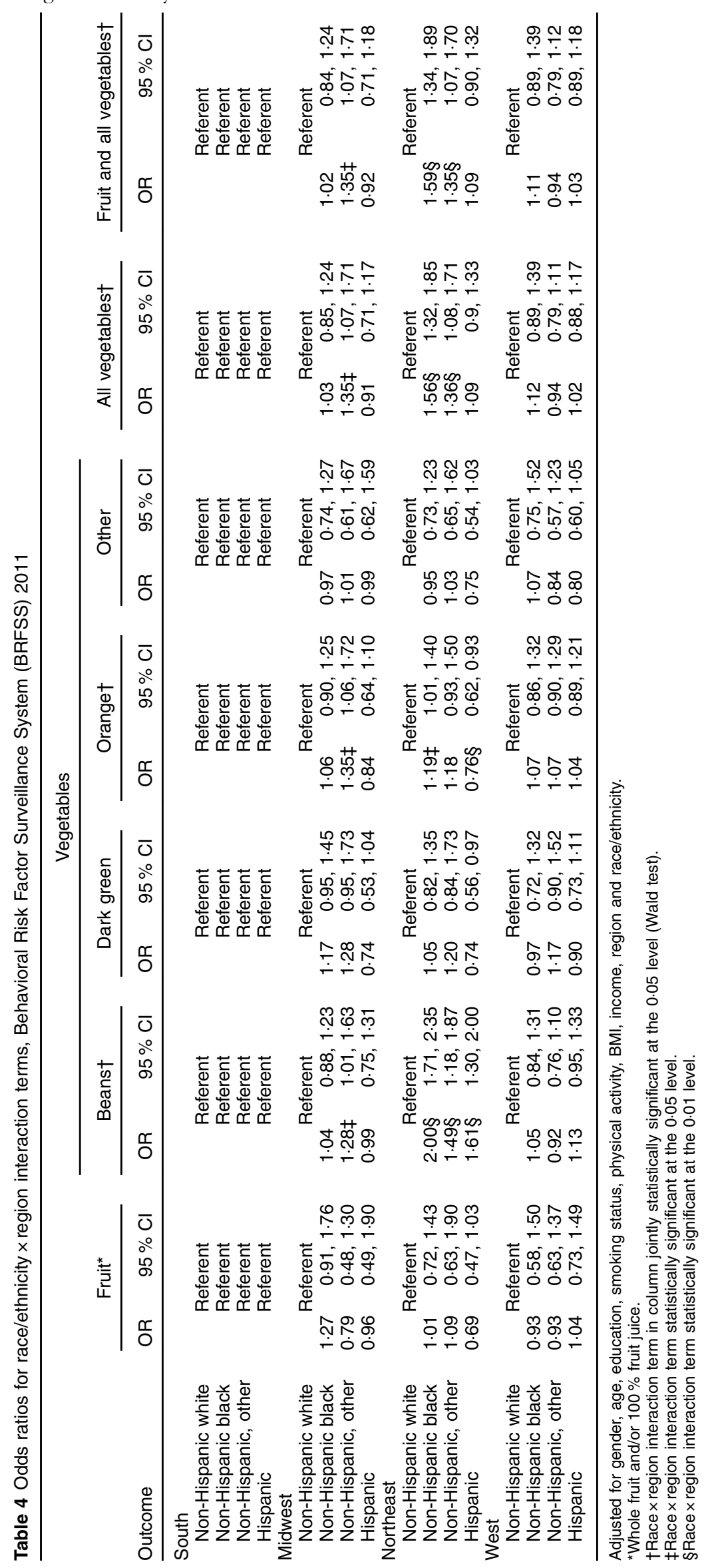




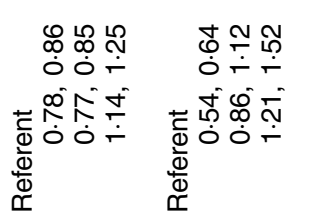

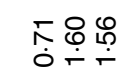

㑒亩

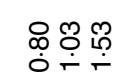

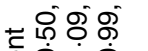

×0ำ

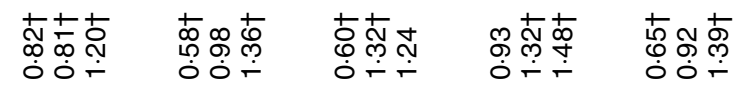

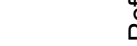

$\frac{\omega}{\omega}$

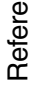

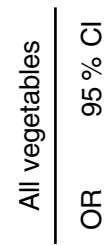

我苾

$\cos 10$

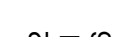

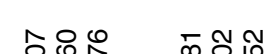

OO- O-

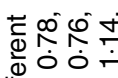

这离

$\llbracket$

충하

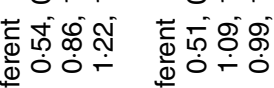

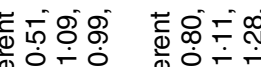

ब्र०-

过

奇号苍

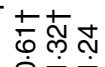

厂

$\frac{\omega}{0}$ O०

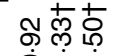

ष융

एक

テ命芯

10

(1)

(1)

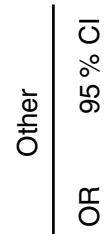

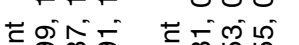

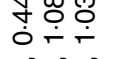

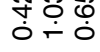

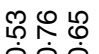

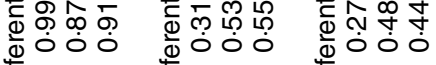

$\stackrel{\square}{\Phi}$

ष्ष

동ㅇํㅇ

$+++$

$\stackrel{\infty}{1}$

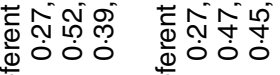

$\widetilde{\alpha}+$

市

$\sin 10$

गुํํํำ

कूठ

ó

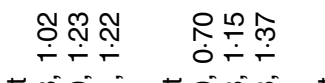

용 웅

舟戈里

ธุำ ำ

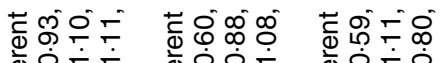

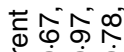

我

这

ปั

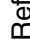

(2)

œ

范

走皮

$\frac{\Phi}{0}$

孛哭芯

ஜํㅇ

음 뜸

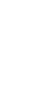

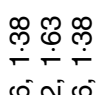

จำล

ลิ ๆ̛̣

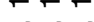

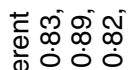

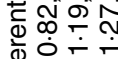

ष्ष

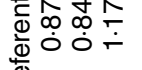

ष्ष

市市市

$\infty 亏$

ब⿺辶寸

ॠ

$\underset{\mathbb{\Phi}}{\mathscr{\Phi}}$

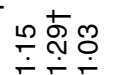

ำ ㅇำ

กำ

क००

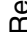

๒

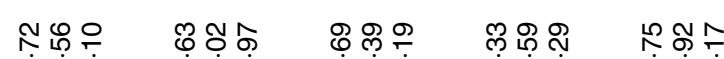

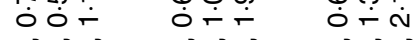

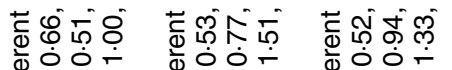

$\ddot{-}-\dot{m}$

든

这

$\widetilde{\infty}$

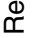

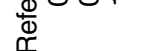

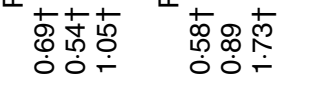

㕝守京

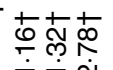

Oं.

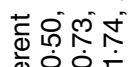
$\frac{\omega}{\Phi}$

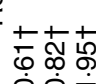

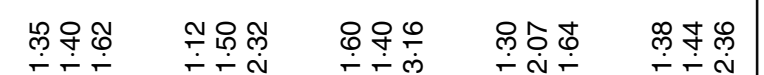

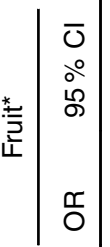

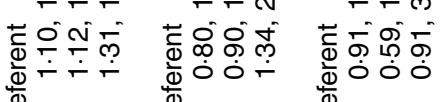

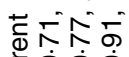

䒕

क्षे

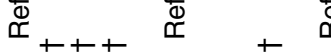

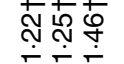

(2)

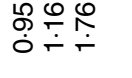

ํํㅇㅎํ

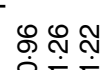

迹品宁-

œ 苦

送

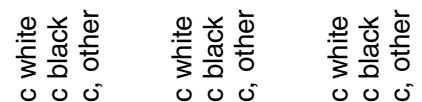

बㅇำ

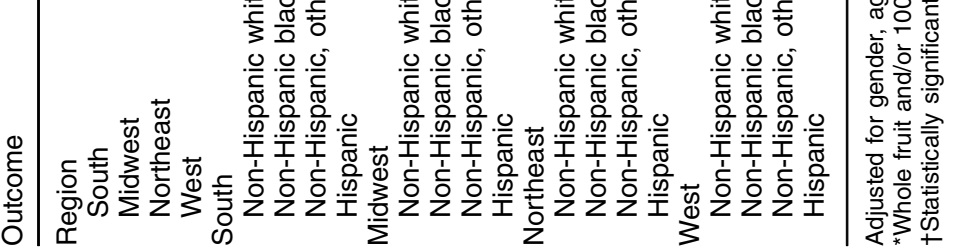


effect between race/ethnicity and region. Non-Hispanic blacks had the lowest prevalence of consuming fruit and all vegetables at least once weekly. Examining the independent and combined effects of race/ethnicity and region of residence, without accounting for effect modification, highlighted non-Hispanic blacks in the Northeast and Midwest as subpopulations with particularly low likelihoods of consumption. However, being non-Hispanic black in the Northeast was associated with a positive effect on consuming fruit and all vegetables $\geq 1$ time/week (Table 4). Compared with other regions, the Northeast appears to provide conditions that positively influence fruit and vegetable consumption among non-Hispanic blacks. Accounting for synergies between race/ethnicity and region in meeting the variety indicators also adds increased precision in targeting: non-Hispanic blacks in the Midwest may be a critical subpopulation to engage with to increase variety of fruit and vegetable consumption.

Regional and cultural dietary patterns may contribute to the effects of race/ethnicity and region that were observed in the present study. For example, Mahaffey et al. ${ }^{(38)}$ found that women living in coastal regions consumed more fish than their non-coastal counterparts and others ${ }^{(39)}$ have described the unique diet pattern of blacks in the South. Additionally, dietary acculturation in foreignborn populations may be a factor contributing to observed synergistic effects. Dietary acculturation tends to reduce fruit and vegetable consumption ${ }^{(40,41)}$, although there are differences between racial/ethnic groups and within ethnic subgroups ${ }^{(41-43)}$. As acculturation increases among Hispanic immigrant populations, consumption of legumes and fruit tends to decrease and non-leguminous vegetable consumption increases ${ }^{(41)}$. More acculturated Hispanics consume diets similar to non-Hispanic whites ${ }^{(41)}$. Far fewer studies document dietary acculturation trends among nonHispanic black foreign-born populations. Those that do often compare this subpopulation with non-Hispanic blacks born in the USA, who tend to consume less fruit ${ }^{(43)}$ and different kinds of vegetables (e.g. more green leafy vegetables and white potatoes, fewer beans and yellow vegetables) ${ }^{(43)}$ than foreign-born, non-Hispanic blacks.

US regions are markedly different from one another in the proportion and diversity of their residents who were born outside the USA ${ }^{(44)}$. New York and New Jersey (located in the Northeast) are the states with the second and third largest percentage of their populations as foreign born, respectively ${ }^{(45)}$. The Northeast is the most diverse region in terms of its foreign-born residents: no country of origin made up $>10 \%$ of the foreign-born population in 2010, unlike other regions ${ }^{(44)}$. Immigrants from the Dominican Republic and Jamaica were two out of top five immigrant groups in the Northeast, whereas there were no black ethnicities among the top five immigrant groups in other regions ${ }^{(45)}$.

The dynamics between dietary acculturation in foreignborn populations and the degree of urbanization within the
Northeast could explain the synergistic effects observed in the present study. Approximately $80 \%$ of the population in the Northeast is located in urban areas, compared with 66 and $63 \%$ in the South and Midwest, respectively ${ }^{(46)}$. Furthermore, four of the top ten most populous urban areas in the USA are located in the Northeast ${ }^{(46)}$. Residing in ethnic enclaves in densely populated urban centres may mediate dietary acculturation via social and/or food environmental structures. For example, Dubowitz et al. ${ }^{(40)}$ observed that the proportion of a neighbourhood that is foreign born was positively associated with individuals' fruit and vegetable consumption, regardless of whether they were foreign or native to the USA.

Local and community-level food environments in the Northeast may contribute favourably towards individuals' fruit and vegetable consumption ${ }^{(47)}$. Fruits, vegetables and nuts represent the majority of direct food sales (e.g. farmers' markets and community-supported agriculture operations) and direct sales are densely concentrated in the Northeast region ${ }^{(48)}$. Of the ten states with the highest share of direct food sales out of total food sales, eight are located in the Northeast ${ }^{(49)}$. A greater proportion of primary grocery shoppers make food purchases at farmers' markets in the Northeast compared with other regions, and they are $\sim 40-60 \%$ more likely to purchase fruits and vegetables through direct sales during some parts of the year compared with other regions ${ }^{(50)}$.

The limitations to the present study are several. It is a cross-sectional analysis, which precludes analysis of time trends in disparities in meeting fruit and vegetable consumption outcomes. A cross-sectional approach was necessary due to the novel design of the 2011 BRFSS module and further research is needed to complement this baseline once subsequent BRFSS data are published. The BRFSS is a telephone survey that relies on self-reported data for information, which may over- or under-report particular characteristics or behaviours. The accuracy of dietary surveys relies on respondents' memory and respondents may adjust their reported consumption patterns to simplify the interview process as well as to impress the interviewer ${ }^{(51,52)}$. Respondents may also differ in how they categorize fruits and vegetables and this may be different between race/ethnic groups ${ }^{(51,53)}$. The BRFSS also does not capture fruits and vegetables consumed as part of mixed dishes. Additionally, the 2010 Dietary Guidelines $^{(33)}$ provide fruit and vegetable recommendations on the basis of daily servings, whereas the BRFSS captures daily frequencies.

Although the National Health and Nutrition Examination Survey (NHANES) provides dietary data on the basis of mass (which can be converted to servings), NHANES data are not collected at the state level and therefore are not as useful as the BRFSS for estimating regional food consumption patterns. Finally, all published studies validating the FFQ module for BRFSS were completed for versions prior to 2011, although a similar version of the 2011 FFQ 
was pilot tested in several states and reliability tested in one state ( $\mathrm{K}$ Grimm, Centers for Disease Control and Prevention, personal communication, 3 April 2013). Further research is needed to assess the validity and reliability of these and other BRFSS modules as a result of the 2011 changes $^{(54)}$.

\section{Conclusion}

The present findings suggest that targeted dietary interventions may be needed for some population groups, such as non-Hispanic blacks in the Midwest. Interventions should focus on increasing consumption of all types of vegetables, particularly orange vegetables and beans. Further research is needed to determine the drivers behind the synergistic effects of race/ethnicity and region in the Northeast and Midwest.

\section{Acknowledgements}

Acknowledgements: The authors gratefully acknowledge Robert Houser, PhD and Parke Wilde, PhD for input on statistical analysis. Financial support: This research received no specific grant from any finding agency in the public, commercial or not-for-profit sectors. Conflict of interest: None. Authorship: N.T. conceived the study. N.T. and Z.C. designed the study, conducted statistical analysis and wrote the manuscript. Both authors read and approved the final manuscript. Ethics of human subject participation: Ethical approval was not required.

\section{References}

1. Danaei G, Ding EL, Mozaffarian D et al. (2009) The preventable causes of death in the United States: comparative risk assessment of dietary, lifestyle, and metabolic risk factors. PLoS Med 6, 1-23.

2. He FJ, Nowson CA, Lucas M et al. (2007) Increased consumption of fruit and vegetables is related to a reduced risk of coronary heart disease: meta-analysis of cohort studies. J Hum Hypertens 21, 717-728.

3. Dauchet L, Amouyel P, Hercberg S et al. (2006) Fruit and vegetable consumption and risk of coronary heart disease: a meta-analysis of cohort studies. J Nutr 136, 2588-2593.

4. Hung H-C, Joshipura KJ, Jiang R et al. (2004) Fruit and vegetable intake and risk of major chronic disease. $J$ Natl Cancer Inst 96, 1577-1584.

5. US Department of Health and Human Services, Centers for Disease Control and Prevention (2010) Ten Leading Causes of Death and Injury. www.cdc.gov/injury/wisqars/ leadingcauses.html (accessed February 2013).

6. Loef M \& Walach H (2012) The combined effects of healthy lifestyle behaviors on all cause mortality: a systematic review and meta-analysis. Prev Med 55, 163-170.

7. Griep LMO, Verschuren WMM, Kromhout D et al. (2012) Variety in fruit and vegetable consumption and 10-year incidence of CHD and stroke. Public Health Nutr 15 , 2280-2286.

8. Murphy SP, Foote JA, Wilkens LR et al. (2006) Simple measures of dietary variety are associated with improved dietary quality. J Am Diet Assoc 106, 425-429.
9. Foote JA, Murphy SP, Wilkens LR et al. (2004) Dietary variety increases the probability of nutrient adequacy among adults. $J$ Nutr 134, 1779-1785.

10. Produce for Better Health Foundation (2015) Fruits and Veggies: More Matters. http://www.fruitsandveggiesmor ematters.org/ (accessed February 2015).

11. Demydas T (2011) Consumer segmentation based on the level and structure of fruit and vegetable intake: an empirical evidence for US adults from the National Health and Nutrition Examination Survey (NHANES) 2005-2006. Public Health Nutr 14, 1088-1095.

12. Grimm KA, Blanck HM, Scanlon KS et al. (2010) Statespecific trends in fruit and vegetable consumption among adults - United States, 2000-2009. MMWR CDC Surveill Summ 59, 1125-1130.

13. Kimmons J, Gillespie C, Seymour J et al. (2009) Fruit and vegetable intake among adolescents and adults in the United States: percentage meeting individualized recommendations. Medscape J Med 11, 26.

14. Casagrande SS, Wang Y, Anderson C et al. (2007) Have Americans increased their fruit and vegetable intake? The trends between 1988 and 2002. Am J Prev Med 32, 257-263.

15. Kant AK, Graubard BI \& Kumanyika SK (2007) Trends in black-white differentials in dietary intakes of US adults, 1971-2002. Am J Prev Med 32, 264-272.

16. Serdula MK, Gillespie C, Kettel-Khan L et al. (2004) Trends in fruit and vegetable consumption among adults in the United States: Behavioral Risk Factor Surveillance System, 1994-2000. Am J Public Health 94, 1014-1018.

17. Newby PK, Noel SE, Grant R et al. (2012) Race and region have independent and synergistic effects on dietary intakes in black and white women. Nutr J 11, 25-36.

18. Newby PK, Noel SE, Grant R et al. (2011) Race and region are associated with nutrient intakes among black and white men in the United States. J Nutr 141, 296-303.

19. Thompson B, Demark-Wahnefried W, Taylor G et al. (1999) Baseline fruit and vegetable intake among adults in seven 5 A Day study centers located in diverse geographic areas. J Am Diet Assoc 99, 1241-1248.

20. Kim SAP, Moore LVP, Galuska DP et al. (2014) Vital signs: Fruit and vegetable intake among children - United States, 2003-2010. MMWR CDC Surveill Summ 63, 671-676.

21. Lutfiyya MN, Chang LF \& Lipsky MS (2012) A cross-sectional study of US rural adults' consumption of fruits and vegetables: do they consume at least five servings daily? BMC Public Health 12, 280.

22. Blanck HM, Gillespie C, Kimmons J et al. (2008) Trends in fruit and vegetable consumption among US men and women, 1994-2005. Prev Chronic Dis 5, 1-10.

23. Forshee RA \& Storey ML (2006) Demographics, not beverage consumption, is associated with diet quality. Int $J$ Food Sci Nutr 57, 494-511.

24. Li R, Serdula M, Bland S et al. (2000) Trends in fruit and vegetable consumption among adults in 16 US states: Behavioral Risk Factor Surveillance System, 1990-1996. Am J Public Health 90, 777-781.

25. Krebs-Smith SM, Cook A, Subar AF et al. (1995) US adults' fruit and vegetable intakes, 1989 to 1991: a revised baseline for the Healthy People 2000 objective. Am J Public Health 85, 1623-1629.

26. Ervin RB (2011) Healthy Eating Index-2005 Total and Component Scores for Adults Aged 20 and Over: National Health and Nutrition Examination Survey, 2003-2004. National Health Statistics Reports no. 44. http://www.cdc. gov/nchs/products/nhsr.htm (accessed November 2014).

27. Diaz VA, Mainous Iii AG, Koopman RJ et al. (2005) Race and diet in the overweight: association with cardiovascular risk in a nationally representative sample. Nutrition 21, $718-725$. 
28. Troost JP, Rafferty AP, Luo Z et al. (2012) Temporal and regional trends in the prevalence of healthy lifestyle characteristics: United States, 1994-2007. Am J Public Health 102, 1392-1398

29. Hajjar I \& Kotchen T (2003) Regional variations of blood pressure in the United States are associated with regional variations in dietary intakes: the NHANES-III data. $J$ Nutr 133, 211-214.

30. US Census Bureau (2010) Geographic Terms and Concepts - Census Divisions and Census Regions. http:// www.census.gov/geo/reference/gtc/gtc_census_divreg.html (accessed November 2014).

31. US Department of Health and Human Services, Centers for Disease Control and Prevention (2013) BRFSS 2011 Survey Data and Documentation: Comparability of Data. http:// www.cdc.gov/brfss/annual_data/annual_2011.htm (accessed April 2014).

32. Hu SS, Balluz L, Battaglia MP et al. (2010) The impact of cell phones on public health surveillance. Bull World Health Organ 88, 799.

33. US Department of Health and Human Services \& US Department of Agriculture (2010) Dietary Guidelines for Americans 2010. Washington, DC: US Government Printing Office; available at http://www.health.gov/dietaryguidelines/

34. US Department of Health and Human Services (2008) 2008 Physical Activity Guidelines for Americans. Washington, DC: US Government Printing Office; available at www. health.gov/paguidelines/guidelines/

35. Muraki I, Imamura F, Manson JE et al. (2013) Fruit consumption and risk of type 2 diabetes: results from three prospective longitudinal cohort studies. BMJ 347, f5001.

36. Marcoe K, Juan WY, Yamini S et al. (2006) Development of food group composites and nutrient profiles for the MyPyramid food guidance system. J Nutr Educ Behav 38, 6 Suppl., S93-S107.

37. Bachman JL, Reedy J, Subar AF et al. (2008) Sources of food group intakes among the US population, 2001-2002. J Am Diet Assoc 108, 804-814.

38. Mahaffey KR, Clickner RP \& Jeffries RA (2009) Adult women's blood mercury concentrations vary regionally in the United States: association with patterns of fish consumption (NHANES 1999-2004). Environ Health Perspect 117, 47-53.

39. Bovell-Benjamin A, Dawkins N, Pace R et al. (2010) Dietary consumption practices and cancer risk in African Americans in the rural South. J Health Care Poor Underserved 21, $57-75$.

40. Dubowitz T, Subramanian SV, Acevedo-Garcia D et al. (2008) Individual and neighborhood differences in diet among low-income foreign and US-born women. Womens Health Issues 18, 181-190.

41. Ayala GX, Baquero B \& Klinger S (2008) A systematic review of the relationship between acculturation and diet among Latinos in the United States: implications for future research. J Am Diet Assoc 108, 1330-1344.

42. Okafor M-TC, Carter-Pokras OD \& Zhan M (2014) Greater dietary acculturation (dietary change) is associated with poorer current self-rated health among African immigrant adults. J Nutr Educ Behav 46, 226-235.

43. Lancaster KJ, Watts SO \& Dixon LB (2006) Dietary intake and risk of coronary heart disease differ among ethnic subgroups of black Americans. J Nutr 136, 446-451.

44. Grieco EM, Trevelyan E, Larsen L et al. (2012) The Size, Place of Birth, and Geographic Distribution of the Foreignborn Population in the United States: 1960 to 2010. Washington, DC: US Government Printing Office; available at http://www.census.gov/people/publications/popwor kingpapers.html

45. Grieco EM, Acosta Y, de la Cruz P et al. (2012) The ForeignBorn Population in the United States: 2010. Washington, DC: US Government Printing Office; available at http:// www.census.gov/topics/population/foreign-born.html\#

46. US Department of Commerce, Census Bureau (2010) Census 2010, Summary File 1, Table P2, generated by Nicole Tichenor. http://www.factfinder2.census.gov (accessed October 2014).

47. US Department of Health and Human Services, Centers for Disease Control and Prevention (2013) State Indicator Report on Fruits and Vegetables, 2013. Table 2. http://www. cdc.gov/nutrition/professionals/data/ (accessed November 2014).

48. Martinez S, Hand M, Da Pra M et al. (2010) Local Food Systems: Concepts, Impacts, and Issues. Washington, DC: US Government Printing Office; available at http://www.ers. usda.gov/media/122868/err97_1_.pdf

49. Diamond A \& Soto R (2009) Facts on Direct-to-Consumer Food Marketing: Incorporating Data from the 2007 Census of Agriculture. http://www.dx.doi.org/10.9752/MS035.052009 (accessed November 2014).

50. Blanck HM, Thompson OM, Nebeling L et al. (2011) Improving fruit and vegetable consumption: use of farmto-consumer venues among US adults. Prev Chronic Dis 8, A49.

51. Roark RA \& Niederhauser VP (2013) Fruit and vegetable intake: issues with definition and measurement. Public Health Nutr 16, 2-7.

52. Woodside JV, Young IS \& McKinley MC (2013) Fruits and vegetables: measuring intake and encouraging increased consumption. Proc Nutr Soc 72, 236-245.

53. Thompson FE, Willis GB, Thompson OM et al. (2011) The meaning of 'fruits' and 'vegetables'. Public Health Nutr 14, $1222-1228$.

54. Pierannunzi C, Hu SS \& Balluz L (2013) A systematic review of publications assessing reliability and validity of the Behavioral Risk Factor Surveillance System (BRFSS), 2004-2011. BMC Med Res Methodol 13, 49. 